\title{
GEOGRAPHIC AND ELEVATIONAL DISTRIBUTION OF FRINGED MYOTIS (MYOTIS THYSANODES) IN COLORADO
}

\author{
Mark A. Hayes ${ }^{1,2}$ and Rick A. Adams ${ }^{1}$
}

\begin{abstract}
Fringed myotis (Myotis thysanodes) is considered a bat species of conservation concern in Colorado and in western North America. The purpose of our research was to describe the geographic and elevational distribution of fringed myotis in Colorado and consider the potential influence of the Southern Rocky Mountains on the distribution of this species. We documented, mapped, and analyzed 729 Colorado capture and occurrence records for this species, and used 546 records in a 2-way ANOVA comparing elevational distribution among sex and reproductive classes. Mean elevation of occurrence was significantly different among reproductive classes $(F=7.03, P=0.0010)$ but not between sex classes $(F=0.10, P=0.7578)$. These elevation results support the hypothesis that fringed myotis tend not to occur at higher elevations in the Southern Rockies. Mapped occurrence records suggest that fringed myotis exhibits a bifurcated geographic distribution, with separate populations occurring in a band along the Colorado Front Range and in western Colorado. These data suggest that the high peaks, mountain parks, and valleys of the Southern Rocky Mountains act as a set of dispersal barriers, and that movement by fringed myotis from east to west, and vice versa, across the Colorado Rockies is not a regular occurence. Finally, populations occurring in southeastern Colorado and in a band along the Colorado Front Range may potentially be at risk from increasing urbanization, changes in surface water resource availability, and exposure to diseases, such as white-nose syndrome.
\end{abstract}

RESUMEN.-El murciélago (Myotis thysanodes) se considera una especie de preocupación para la conservación en Colorado y en el oeste de América del Norte. El objetivo de esta investigación fue describir la distribución geográfica y altitudinal de M. thysanodes en Colorado y considerar la posible influencia de las Montañas Rocosas del Sur en la distribución de esta especie. Documentamos, mapeamos y analizamos 729 registros de captura y ocurrencia de esta especie en Colorado y utilizamos 546 registros en un ANOVA de dos vías comparando la distribución de altitud entre clases sexuales y reproductivas. La elevación de ocurrencia promedio fue significativamente diferente entre las clases reproductivas $(F=7.03, P=0.0010)$, pero no entre las clases sexuales $(F=0.10, P=0.7578)$. Estos resultados de altitud respaldan la hipótesis de que los murciélagos de la especie $M$. thysanodes no tienden a encontrarse en las elevaciones más altas de las Montañas Rocosas del Sur, y registros georeferenciados sugieren que estos murciélagos presentan una distribución geográfica bifurcada con poblaciones separadas que se encuentran a lo largo de la cordillera central (Front Range) de Colorado y en el oeste de Colorado. Esta información sugiere que las altas cimas, los parques de montaña y los valles de las Montañas Rocosas del Sur actúan como un conjunto de barreras de dispersión, y que el movimiento de los murciélagos de este a oeste, y viceversa, a través de las Montañas Rocosas de Colorado no ocurre con frecuencia. Por último, las poblaciones que se encuentran en el sureste de Colorado y a lo largo de la cordillera central (Front Range) de Colorado podrían estar expuestas a los riesgos de la creciente urbanización, los cambios en la disponibilidad de agua superficial y a la exposición a enfermedades, tales como el síndrome de la nariz blanca.

Fringed myotis (Myotis thysanodes) is a relatively large-bodied, insectivorous Myotis with long ears (average mass of individuals in Colorado typically 6-7 g, average ear length 16-21 mm; Adams 2003, Armstrong et al. 2011). The key external feature that distinguishes this species from other Myotis in Colorado is the distinctive fringe of short, stiff hairs on the trailing edge of the tail membrane (uropatagium) (O’Farrell and Studier 1980, Armstrong et al. 2011).

The known geographic distribution of fringed myotis extends from just south of the Isthmus of Tehuantepec, north through central Mexico associated with the western slopes of the Sierra Madre Oriental, the Central Plateau, and the eastern slopes of the Sierra Madre Occidental, and throughout the western and southwestern United States to southern British Columbia (O’Farrell and Studier 1980, Wilson and Reeder 2005). There are currently 3 recognized subspecies of fringed myotis (O'Farrell and Studier 1980, Wilson and Reeder 2005). O’Farrell and Studier (1980) recognized Myotis thysanodes aztecus as being associated with the Isthmus of Tehuantepec region. Jones and Genoways

\footnotetext{
${ }^{1}$ School of Biological Sciences, University of Northern Colorado, Greeley, CO 80639

${ }^{2}$ Present address: 923 Pioneer Ave., Fort Collins, CO 80521. E-mail: hayes.a.mark@gmail.com
} 
(1967) described Myotis thysantodes pahasapensis as being associated with the Black Hills region of South Dakota and Wyoming. The remaining populations of fringed myotis are currently considered to be Myotis thysanodes thysanodes (O’Farrell and Studier 1980, Wilson and Reeder 2005).

Armstrong (1972) included fringed myotis as a member of the Chihuahuan faunal element with possible evolutionary origins in the basins and ranges of Chihuahua, Coahuila, and Durango, Mexico. Armstrong proposed that members of the Chihuahuan faunal element have geographic distributions that bifurcate around the Southern Rocky Mountains, a region which features high-elevation mountain ranges, mountain parks and valleys, and the Continental Divide. This bifurcated distribution minimizes dispersal among populations on the eastern and western slopes of the Colorado Rockies. Fringed myotis has been found in the tablelands of southeastern Colorado, at several high plains sites in areas with physiographic relief, at lower elevations of the Southern Rocky Mountains, and on the Colorado Plateau (Armstrong et al. 1994, 2011, Adams 2003). Fringed myotis appears to exist in lowdensity populations in suitable habitats in Colorado and has been observed associated with a narrow band of ponderosa pine forests along the Colorado Front Range at elevations up to $2400 \mathrm{~m}$ (Armstrong et al. 1994, Adams 2003). Armstrong et al. (1994), Adams (2003), and Armstrong et al. (2011) proposed distributions for this species that concurred with the Chihuahuan distribution hypothesis. However, a conservation assessment for this species in the Rocky Mountain region implied a broader distribution for fringed myotis in the Southern Rocky Mountains (Keinath 2004).

Fringed myotis is considered a species of conservation concern in Colorado and in western North America. In 1994, fringed myotis was designated as a Category 2 candidate for listing under the United States Endangered Species Act (USFWS 1994). Since 1996 when the Category 2 Endangered Species Act designation was eliminated, fringed myotis has been considered a "species of concern" in the western United States (USFWS 1996, O’Shea et al. 2003). In 1998, the Western Bat Working Group developed a bat conservation priority matrix defining 10 ecoregions for the western United States and listed fringed myotis as "red or high" priority in 4 regions and "yellow or medium" priority in 6 other regions. The United States Forest Service lists fringed myotis as a "sensitive species" in the Rocky Mountain Region (United States Forest Service 2006). Fringed myotis is listed as a mammal of "greatest conservation concern" by the Colorado Division of Wildlife's 2005 Comprehensive Wildlife Conservation Strategy and is described as having low population status, with unknown population trends (CDOW 2005).

Despite a substantial amount of bat survey work and research in Colorado during the past 2 decades, no recent attempt has been made to update and evaluate the geographic distribution of fringed myotis in Colorado and the Southern Rocky Mountain region. The last fringed myotis occurrence data in Colorado was compiled, mapped, and analyzed by Armstrong et al. (1994) using 23 occurrence records. The purpose of our research was to compile, map, and analyze all currently available fringed myotis occurrence data and describe the current geographic and elevational distribution of this species in Colorado.

\section{Methods}

\section{Study Area, Data Collection, and Analysis}

We compiled all available data on capture and occurrence locations of fringed myotis in Colorado. We obtained this information from the primary literature, Colorado Division of Wildlife documents and databases, museum records, and the records, reports, and field notes of bat researchers, mammalogists, and others who have conducted bat surveys and research in Colorado. This information included occurrence records for fringed myotis from the Colorado Bats/Inactive Mines Project, which has conducted over 3000 capture and internal surveys at abandoned mines throughout Colorado since 1991 (Navo and Krabacher 2005; K. Navo personal communication). Fringed myotis can be confused with some other western myotis species, especially western long-eared myotis (Myotis evotis). The key external feature that distinguishes fringed myotis from other myotis in Colorado is the distinctive fringe of short, stiff hairs on the trailing edge of the tail membrane (O'Farrell and Studier 1980, Armstrong et al. 2011). We carefully evaluated fringed myotis records and eliminated records that were likely to have not 
been recorded by a biologist capable of distinguishing fringed myotis from other western myotis species. We also conducted mist-netting and roost monitoring to identify new fringed myotis occurrence locations (Hayes 2011). These Colorado fringed myotis occurrence locations were then mapped. We also evaluated the following distribution hypotheses, based on currently available occurrence records: (1) the broad distribution hypothesis, which proposes that fringed myotis occur throughout the Colorado Rockies; and (2) the bifurcated distribution hypothesis, which proposes that fringed myotis do not occur throughout the Colorado Rockies, but occur in southeastern Colorado and a band along the Colorado Front Range and in western Colorado and not in the higher mountains and valleys of the Colorado Rockies.

This occurrence data set was used to perform a 2-way ANOVA comparing the elevation of occurrence among levels within reproductive and sex classes:

$$
X_{i j k}=\mu+\alpha_{i}+\beta_{i}+\alpha_{i} \beta_{i}+\varepsilon_{i j k},
$$

where $X_{i j k}$ is the elevation of the individual occurrence record, $\mu$ is the mean elevation of all fringed myotis records, $\alpha_{i}$ is reproductive class for the individual record $(j=$ juvenile, $n=$ nonreproductive adult, and $r=$ reproductive adult $), \beta_{j}$ is the sex class $(\mathrm{m}=$ male, $\mathrm{f}=$ female), and $\varepsilon_{i j k}$ is an error term. ANOVA analysis was conducted with the general linear model (GLM) procedure using SAS 9.1 statistical software (SAS Institute, Inc., Cary, NC). We checked for interaction between the main effects using a plot of age and sex classes and levels against elevation.

Finally, we considered the potential influences of the Southern Rocky Mountains on fringed myotis distribution patterns in Colorado, especially as potential barriers to dispersal across the Colorado Rockies. We also considered the potential impacts of urbanization and changing water resource availability on fringed myotis populations, and potential susceptibility of populations of this species on the eastern slope of the Colorado Rockies and in southeastern Colorado to exposure to bat white-nose syndrome.

We followed the guidelines of the American Society of Mammalogists (Sikes et al. 2011) and Colorado Division of Wildlife collection permits when capturing and handling live bats. All research was conducted after review and approval by the Institutional Animal Care and Use Committee of the University of Northern Colorado under permit number 0706.

\section{RESUlTS}

We documented 729 capture and occurrence records of fringed myotis in Colorado (see Hayes 2011 for a full list of these records). Using these capture and occurrence records, we created an ArcGIS map showing capture and occurrence locations in Colorado (Fig. 1). Of these records we used 546 fringed myotis records that included information about sex, reproductive status, and elevation of occurrence $(m)$ to calculate descriptive statistics for each sex and reproductive class (female, nonreproductive: $\bar{x}_{f n}=1976, \sigma=235$; female, reproductive: $\bar{x}_{f r}=1862, \sigma=98$; male, nonreproductive: $\bar{x}_{m n}=2003, \sigma=257$; male, reproductive: $\bar{x}_{m r}=1941, \sigma=284$; female and male juveniles: $\bar{x}_{j}=1843, \sigma=166$; Table $1)$ and to perform the 2-way ANOVA comparing elevational distribution among sex and reproductive classes (Table 2); 183 records were not used in this analysis because they lacked data about sex, reproductive status, and/or elevation. Mean elevation of occurrence were significantly different among reproductive classes $(F=7.03, P=0.0010)$ but not between sex classes $(F=0.10, P=0.7578)$. Student-Neuman-Keuls (SNK) test results comparing reproductive and sex classes are shown in Table 3. In the SNK groupings, means with the same letter are not considered to be significantly different. Sex class groupings do not suggest a significant difference between mean elevation of males and females $\left(\bar{x}_{m}=1920 \mathrm{~m}\right.$; $\bar{x}_{f}=1892 \mathrm{~m}$; Table 3). However, reproductive class groupings suggest a significant difference in mean elevation of occurrence between reproductive and nonreproductive adults and juveniles $\left(\bar{x}_{r}=1884 \mathrm{~m}, \bar{x}_{n}=1950 \mathrm{~m}, \bar{x}_{j}=\right.$ $1843 \mathrm{~m}$; Table 3). A boxplot of elevation of occurrence versus sex and reproductive status suggests that there is ordinal interaction between reproductive and sex classes, but that the main effects can be interpreted independently of each other (Fig. 2).

\section{Discussion}

In the Southwestern Tablelands of southeastern Colorado, the fringed myotis was documented in the Black Mesa and Purgatoire 


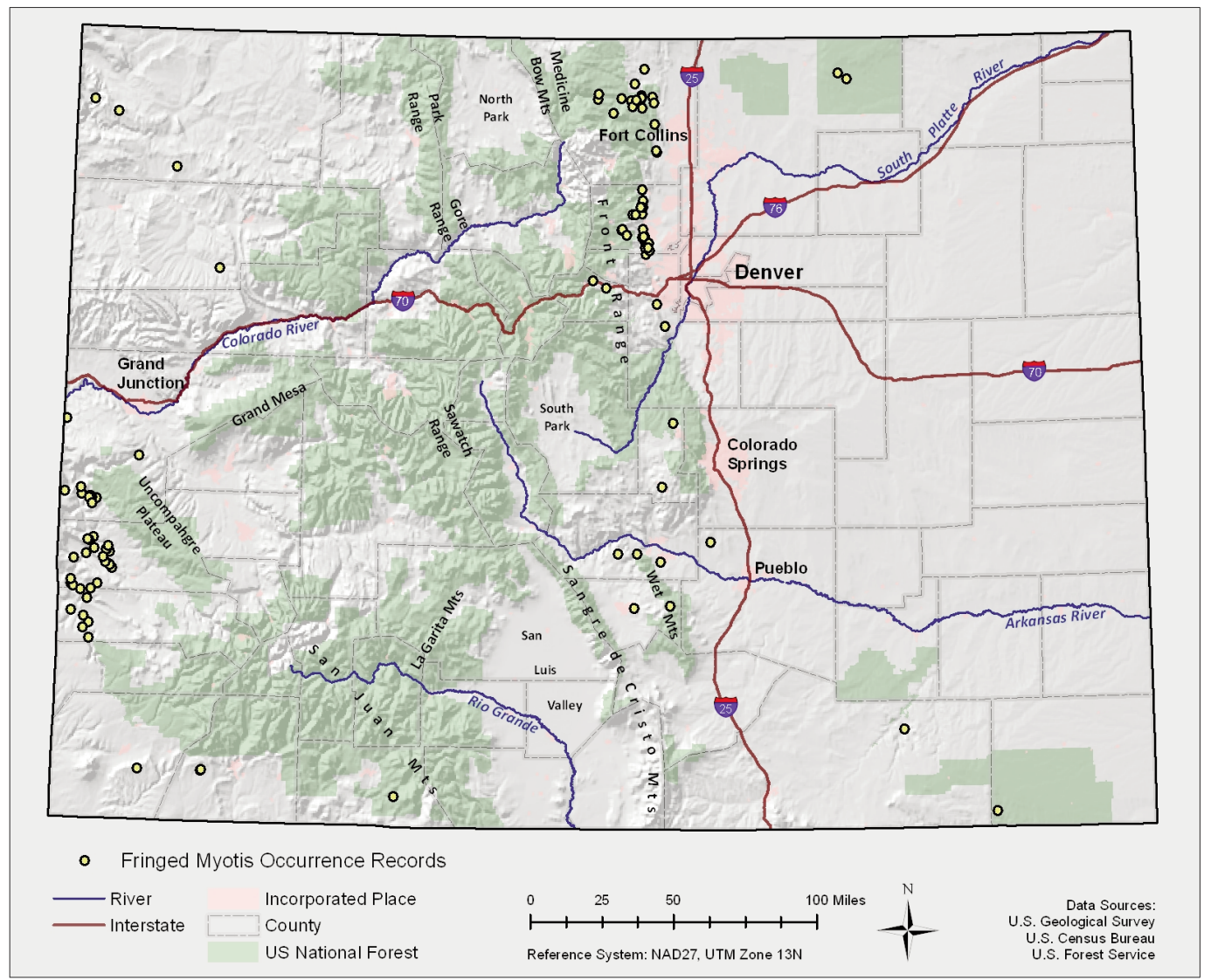

Fig. 1. Map of 729 capture and occurrence locations of fringed myotis (Myotis thysanodes) from Colorado (yellow dots).

TABLE 1. Number $(N)$, average elevation $(\bar{X}$, in meters), standard deviation $(\sigma)$, and $95 \%$ confidence interval for 546 individual records of fringed myotis (Myotis thysanodes) from Colorado.

\begin{tabular}{lrrrr}
\hline Sex and reproductive class & $N$ & $\bar{X}$ & $\sigma$ & $95 \%$ CI \\
\hline Female, nonreproductive & 68 & 1976 & 235 & $1948-2005$ \\
Female, reproductive & 220 & 1862 & 98 & $1855-1868$ \\
Male, nonreproductive & 144 & 2003 & 257 & $1982-2024$ \\
Male, reproductive & 49 & 1941 & 284 & $1900-1981$ \\
Juvenile & 65 & 1843 & 166 & $1822-1863$ \\
\hline
\end{tabular}

Canyon areas, and is likely to occur throughout the Mesa de Maya, Black Mesa, Pugatoire hills and canyons, and piñon-juniper woodlands and savannas of southeastern Colorado. Fringed myotis was not documented in the pineoak woodlands of Castle Rock and the Black Forest, but it seems likely that the species inhabits this ecoregion. Fringed myotis may also occur in the piedmont plains and tablelands in areas with suitable roosting and water resources. In the High Plains of northeastern
Colorado, this species was documented near Pawnee Buttes and may occur in other areas of moderate-relief plains where suitable resources are available, especially in areas adjacent to foothills or tablelands. Fringed myotis was documented in the foothills shrublands and midelevation forests of the eastern slopes of the Colorado Rockies from the Wet Mountains north along the Pikes Peak massif west of Colorado Springs and the Front Range to the Wyoming state line, and due to similar habitat 
TABLE 2. Analysis of variance with reproductive class and sex class as main effects and the interaction (Repro* Sex). Sample size was 546 individual fringed myotis (Myotis thysanodes) from Colorado. $\mathrm{df}=$ degrees of freedom.

\begin{tabular}{|c|c|c|c|c|}
\hline Source & $\mathrm{df}$ & Mean square & $F$ & $\operatorname{Pr}>F$ \\
\hline Reproductive class & 2 & 330,931 & 7.03 & 0.0010 \\
\hline Sex class & 1 & 4478 & 0.10 & 0.7578 \\
\hline Repro * Sex & 2 & 124,495 & 2.65 & 0.0718 \\
\hline
\end{tabular}

TABLE 3. Student-Newman-Keuls (SNK) test results comparing reproductive and sex classes using 546 individual records of fringed myotis (Myotis thysanodes) from Colorado. In the SNK groupings, means with the same letter are not significantly different.

\begin{tabular}{llll}
\hline Mean elevation $(\mathrm{m})$ & $N$ & Class & SNK groupings \\
\hline \multirow{2}{*}{1920} & 233 & Sex class & Sex grouping \\
\cline { 3 - 4 } 1892 & 313 & Male & $\mathrm{A}$ \\
& & Female & $\mathrm{A}$ \\
\cline { 3 - 4 } & & Reproductive class & Reproductive grouping \\
\cline { 3 - 4 } 1950 & 210 & Nonreproductive & $\mathrm{A}$ \\
1884 & 271 & Reproductive & $\mathrm{B}$ \\
\hline
\end{tabular}

and elevation is likely to occur throughout the foothills shrublands and midelevation forests on the east slopes of the Sangre de Cristo mountains and Culebra range of southern Colorado. It also seems likely that this species occasionally disperses from the foothills shrublands and midelevation forests in the La Veta Pass area into the west slopes of the Sangre de Cristo and Culebra mountains. Fringed myotis is not known to occur in the Arizona/New Mexico Plateau ecoregion in the San Luis Valley. The alluvial flats and wetlands, salt flats, and sand dunes and sand sheets of this ecoregion are unlikely to provide suitable roosting resources for this species, except as available in human structures. It is possible that small populations of this species occur in the San Luis shrublands and hills in the southern part of the San Luis Valley, and on the eastern slopes of the San Juan and La Garita Mountains adjacent to the San Luis Valley.

In the Colorado Plateaus of western Colorado, fringed myotis has been documented in the Monticello-Cortez uplands and sagebrush valleys, and semiarid benchlands and canyonlands. In particular, this species has been extensively documented using abandoned mines in the mesas, valleys, and canyonlands west of the Uncompahgre Plateau. However, during a study of the bats of Mesa Verde National Park, Colorado, in 2006 and 2007 (120 nights of sampling), fringed myotis represented only $2 \%$ of captures (41 fringed
myotis-O'Shea et al. 2011). Although fringed myotis has not been documented in the escarpments north of the Grand Valley, it is likely that this species occurs in this area where suitable water resources are present. Fringed myotis has also not, to our knowledge, been documented in the Wyoming Basin in northwestern Colorado. However, this species has been documented in the semiarid benchlands and canyonlands in Dinosaur National Monument and Canyon Lodore, and it seems likely that it occurs in areas with suitable roosting and water resources in the adjacent Wyoming Basin (Hayes 2011). The only records of fringed myotis in the midelevation forests of western Colorado are from a maternity colony in an abandoned cabin near Pagosa Springs in the San Juan Mountains. Although limited bat capture and survey work has been conducted in the forests of western Colorado, we expect that this species occurs regularly in the midelevation forests of western Colorado from the western slopes of the San Juan Mountains to the western slopes of the West Elk Mountains, Grand Mesa, the Flat Tops, and the Elk Head, Sierra Madre, and Gore ranges.

These results support the Chihuahuan distribution hypothesis (Armstrong 1972) that fringed myotis exhibits a bifurcated geographic distribution with populations in southeastern Colorado and in a band along the Front Range of the Colorado Rockies being separate from populations in western Colorado (Armstrong 


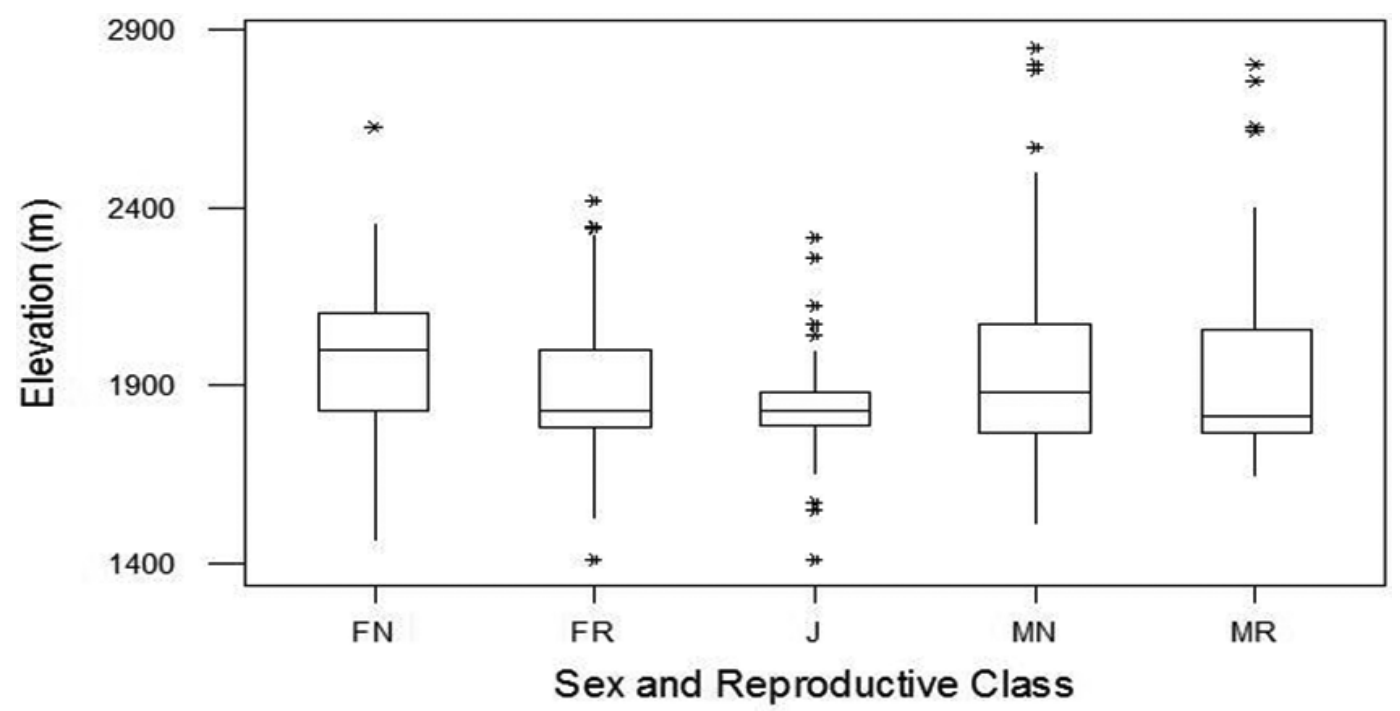

Fig. 2. Box plot of elevation of occurrence for fringed myotis (Myotis thysanodes) in Colorado versus sex and reproductive classes. $\mathrm{FN}=$ adult nonreproductive females; $\mathrm{FR}=$ adult reproductive females (pregnant, lactating, or postlactating); $\mathrm{J}=$ juveniles (male and female combined); $\mathrm{MN}=$ adult nonreproductive males; $\mathrm{MR}=$ adult reproductive males. Total number of individual records is 546. These plots show the distributional characteristics of the data, including medians, quartiles, and outliers.

1972, Armstrong et al. 1994, Adams 2003, Armstrong et al. 2011). This data set does not support the broader distribution hypothesis that fringed myotis occurs throughout the Southern Rocky Mountains. The mean elevation of occurrence of fringed myotis in Colorado was $\sim 2000 \mathrm{~m}$, with the maximum recorded elevation <2900 m (Table 1, Fig. 2). Many mountain ranges and passes in Colorado and the Southern Rocky Mountains exceed 3300 m, and it seems likely that if fringed myotis regularly moved over these high mountain features that this species would occasionally be documented at higher elevations. Thus, we interpret these results as suggesting that the higher elevations of mountain ranges, mountain parks and valleys, and the Continental Divide of the Southern Rocky Mountains minimize or prevent regular movement between populations on the eastern and western slopes of the Colorado Rockies.

Mountains have long been known to influence and shape the distribution of bat species. Merriam (1890) commented on the different bat species observed in the Sonoran Desert and Grand Canyon compared to the forests of the San Francisco Mountains in Arizona, and mammalogists in the late 1800s through the mid 1900s often framed comments and dis- cussions of fringed myotis distribution within Merriam's life zone concept, which used elevation and annual precipitation to define life zones (Merriam 1895). For example, Miller described the distribution of fringed myotis as follows: "Lower Sonoran zone from the southern border of the Western United States to San Luis Potosi and Michoacán" (Miller 1897:80). Likewise, Grinnell (1918) noted that most fringed myotis records from California were from the Upper Sonoran Life Zone. Bailey (1931) also concluded that most fringed myotis records from New Mexico occurred in the Upper Sonoran Life Zone, with the breeding range of the species likely occurring in the Lower and Upper Sonoran Life Zones. Findley (1969) discussed in some detail how mountains can influence the distribution patterns of mammals, including bats, in the southwestern and desert landscapes of North America. Armstrong (1972) developed a distribution classification scheme for mammals in North America based in large part on the influence of mountains on mammalian distribution patterns.

Modern researchers have further developed Merriam's observation that elevation and precipitation influence bat distribution patterns and have emphasized the thermoregulatory 
constraints imposed by the general pattern of decreased ambient temperatures at the higher elevations associated with mountain ranges (McNab 1969, 1982a, 1982b, Armstrong 1972, Graham 1983, Patterson et al. 1996, Soriano et al. 1999, Cryan et al. 2000, McCain 2007, Willig et al. 2009, Willey 2010). Soriano et al. (1999) analyzed the biogeographic influences of the Andes Mountains in Venezuela on mammalian and bat distribution patterns and concluded that the Andes Mountains have significantly influenced the speciation, distribution, and evolutionary patterns of the mammalian species associated with this mountain chain. McCain (2007) investigated the relationship of bat species richness with temperature and elevational gradients in large mountain ranges on several continents and concluded that bat species richness is maximized when mean ambient temperatures are relatively high and when water is reliably available. Cryan et al. (2000) and Willey (2010) investigated the influence of mountains and elevation on bat distribution patterns in the Southern and Central Rocky Mountains and the Black Hills region, and concluded that these patterns are due in part to thermoregulatory constraints, especially on reproductive females, and on the availability of water and food resources.

In the Southern Rocky Mountains, there are significant constraints on the distribution of fringed myotis throughout this species' annual life cycle. Although fringed myotis is suspected to undertake short migrations (Hoffmeister 1970, Studier and O'Farrell 1972), it is not known to be a strongly migratory bat (O'Farrell and Studier 1980). Therefore, for viable populations to persist in an area of the Colorado Rockies, suitable and available hibernacula, maternity sites, water, food, and mating opportunities must typically occur within an individual's annual home range. These combined factors may limit the dispersal ability of fringed myotis, especially over major geographic barriers such as high mountains, mountain passes, and mountain valleys and parks that often do not offer forest structure, suitable ambient temperatures for reproduction and hibernation, readily available water resources, or predictable food supplies. Dispersal from west to east across the Southern Rocky Mountains, and vice versa, do not seem likely for a bat species that is not known to be a strong disperser. A more likely route of dispersal would be around the Southern Rocky Mountains by dispersal north into Wyoming or south into New Mexico. The distance for such dispersal would likely be much longer than dispersal for a strongly migratory species, because the bats would likely disperse along forested corridors, which would be primarily on the edges of mountain parks and valleys, making the actual dispersal distance significantly longer. Thus, we conclude that these data support the hypothsis that the high peaks and mountains parks and valleys of the Southern Rocky Mountains act as a set of dispersal barriers, making it difficult for individual fringed myotis to successfully move across all barriers. Regular movement by fringed myotis from east to west or vice versa across the Colorado Rockies seems unlikely.

Further, we suggest that the separate population occurring in southeastern Colorado and in a band along the Colorado Front Range may potentially be at risk from rapid urbanization and exposure to the disease bat white-nose syndrome. The Colorado Front Range is characterized by some of the most rapid urbanization in North America (Grimm et al. 2008), resulting in environmental modifications and habitat fragmentation (Magle et al. 2009). Rapid urbanization has occurred from Pueblo to Fort Collins, with the most expansive growth and development centered around Denver (Magle et al. 2009). Because the distribution of fringed myotis coincides with rapid urbanization, this species may be influenced by increased recreational activity near roost sites and by changes in water resource availability resulting from increased urban and agricultural water use. Furthermore, there has been increased concern regarding the influences of anthropogenic and climate changes on water resources (Arnell 2004, Christensen and Lettenmaier 2006, Björk and Molau 2007, Kang and Ramírez 2007, Ray et al. 2008, Saunders et al. 2008, Auble et al. 2009) and on bats, including fringed myotis, in the Southern Rocky Mountains (Adams and Hayes 2008, Adams 2010). We also conclude that the apparently separate fringed myotis populations occurring in southeastern Colorado and in a band along the Colorado Front Range may potentially be at risk from exposure to the bat disease white-nose syndrome. This devastating disease has had substantial impacts on 
some myotis populations in eastern North America (Frick et al. 2010, USFWS 2012), and it is possible that populations of fringed myotis east of the Continental Divide may be at risk from this disease.

Given that these results support the Chihuahuan distribution hypothesis (Armstrong 1972) that the fringed myotis distribution bifurcates around the high peaks and mountain valleys of the Southern Rocky Mountains, the geographic area occupied by this species in Colorado may be substantially less than would be occupied if fringed myotis occurred throughout the Colorado Rockies. The information presented here should help guide conservation and management planning efforts in the Southern Rocky Mountains, including consideration of the potential influences of urbanization and a changing climate on this species. Future species occupancy studies (MacKenzie et al. 2002, 2006) using capture and acoustic techniques (Gorresen et al. 2008, Weller 2008) or species distribution modeling using capture and acoustic data (Jaberg and Guisan 2001, Elith and Leathwick 2009, Rodhouse et al. 2012) in the Southern Rocky Mountains would help refine our understanding of the distribution of fringed myotis, and other bat species, in Colorado and in the Southern Rocky Mountain region.

\section{ACKNOWLEDGMENTS}

The Colorado Wildlife Conservation Grant program, administered cooperatively by the Colorado Division of Wildlife and the U.S. Fish and Wildlife Service, was generous in supporting this research. The U.S. Department of Education's GAANN Doctoral Fellowship Program and the School of Biological Sciences at University of Northern Colorado also provided financial support over several years. K. Fishburn created the map in Fig. 1. K. Navo, P. Cryan, L. Bonewell, and anonymous reviewers made thoughtful and helpful comments during various phases of this project.

\section{Literature Cited}

ADAms, R.A. 2003. Bats of the Rocky Mountain West: natural history, ecology, and conservation. University Press of Colorado, Boulder, CO.

2010. Bat reproduction declines when conditions mimic climate change projections for western North America. Ecology 91:2437-2445.
Adams, R.A., And M.A. Hayes. 2008. Water availability and successful lactation by bats as related to climate change in arid regions of western North America. Journal of Animal Ecology 77:1115-1121.

Armstrong, D.M. 1972. Distribution of mammals of Colorado. Monograph, University of Kansas Museum of Natural History, 3. University of Kansas Printing Service, Lawrence, KS.

Armstrong, D.M., R.A. Adams, and J. Freeman. 1994. Distribution and ecology of bats of Colorado. Natural History Inventory of Colorado, No. 15:1-83.

Armstrong, D.M., C.A. Meaney, and J.P. Fitzgerald. 2011. Mammals of Colorado. 2nd edition. Denver Museum of Natural History and University Press of Colorado, Niwot, CO.

ArNell, N.W. 2004. Climate change and global water resources: SRES emissions and socio-economic scenarios. Global Environmental Change 14:31-52.

Auble, G.T., M. Wondzell, and C. Talbert. 2009. Decision support system for evaluation of Gunnison River flow regimes with respect to resources of the Black Canyon of the Gunnison National Park. Open file report 2009-1126, United States Geological Survey.

BaILEY, V. 1931. Mammals of the southwestern United States (with special reference to New Mexico). United States Biological Survey, Department of Agriculture, North American Fauna 53:1-412.

BJörk, R.G., and U. Molau. 2007. Ecology of alpine snowbeds and the impact of global change. Arctic, Antarctic, and Alpine Research 39:34-43.

Christensen, N., and D.P. Lettenmaier. 2006. A multimodel ensemble approach to assessment of climate change impacts on the hydrology and water resources of the Colorado River Basin. Hydrology and Earth System Science Discussions 3:3727-3770.

[CDOW] Colorado Division of Wildlife. 2005. Colorado's Comprehensive Wildlife Conservation Strategy: including references to wildlife action plans. Colorado Division of Wildlife, Denver, CO.

Cryan, P.M., M.A. Bogan, and J.S. Altenbach. 2000. Effect of elevation on distribution of female bats in the Black Hills, South Dakota. Journal of Mammalogy 81:719-725.

Elith, J., and J.R. Leathwick. 2009. Species distribution models: ecological explanation and prediction across space and time. Annual Review of Ecology, Evolution, and Systematics 40:677-697.

FINDLEY, J.S. 1969. Biogeography of southwestern boreal and desert mammals. In: J. Knox Jones Jr., editor, Contributions in mammalogy: a volume honoring professor E. Raymond Hall. Museum of Natural History, University of Kansas, Lawrence, KS.

Frick, W.F., J.F., Pollock, A.C. Hicks, K.E. Langwig, D.S. Reynolds, G.G. Turner, C.M. ButchKoski, AND T.H. KUNZ. 2010. An emerging disease causes regional population collapse of a common North American bat species. Science 329:679-682.

Gorresen, P.M., A.C. Miles, C.M. TodD, FJ. Bonaccorso, AND T.J. WELLER. 2008. Assessing bat detectability and occupancy with multiple automated bat detectors. Journal of Mammalogy 89:11-17.

Graham, G.L. 1983. Changes in bat diversity along an elevational gradient up the Peruvian Andes. Journal of Mammalogy 64:559-571.

Grimm, N.B., D. Foster, P. Groffman, J.M. Grove, C.S. Hopkinson, K.J. Nadelhoffer, D.E. Pataki, and D.P.C. Peters. 2008. The changing landscape: 
ecosystem responses to urbanization and pollution across climatic and societal gradients. Frontiers in Ecology and Environment 6:264-272.

Grinnell, H.W. 1918. A synopsis of the bats of California. University of California Publications in Zoology 17:223-404.

Hayes, M.A. 2011. An analysis of fringed myotis (Myotis thysanodes) with a focus on Colorado distribution, maternity roost selection, and preliminary modeling of population dynamics. Doctoral dissertation, University of Northern Colorado, Greeley, CO.

Hoffmeister, D.F. 1970. The seasonal distribution of bats in Arizona: a case for improving mammalian range maps. Southwestern Naturalist 15:11-22.

Jaberg, C., and A. Guisan. 2001. Modelling the distribution of bats in relation to landscape structure in a temperate mountain environment. Journal of Applied Ecology 38:1169-1181.

Jones, J.K., JR. and H.H. GenOways. 1967. A new subspecies of the fringe-tailed bat, Myotis thysanodes, from the Black Hills of South Dakota and Wyoming. Journal of Mammalogy 48:231-235.

KanG, B., AND J.A. Ramírez. 2007. Response of streamflow to weather variability under climate change in the Colorado Rockies. Journal of Hydrologic Engineering 12:63-72.

Keinath, D.A. 2004. Fringed myotis (Myotis thysanodes): a technical conservation assessment. USDA Forest Service, Rocky Mountain Region, Species Conservation Project, Cheyenne, WY.

MacKenzie, D.I., J.D. Nichols, G.B. Lachman, S. Droege, J.A. Royle, And C.A. Langtimm. 2002. Estimating site occupancy rates when detection probabilities are less than one. Ecology 83:2248-2255.

Mackenzie, D.I., J.D. Nichols, J.A. Royle, K.H. PolLACK, L.L. BaILEY, and J.E. Hines. 2006. Occupancy estimation and modeling: inferring patterns and dynamics of species occurrence. Elsevier/Academic Press, Burlington, MA.

MCCAIN, C.M. 2007. Could temperature and water availability drive elevational species richness patterns? A global case study for bats. Global Ecology and Biogeography 16:1-13.

NCNAB, B.K. 1969. The economics of temperature regulation in neotropical bats. Comparative Biochemistry and Physiology 31:227-268.

. 1982a. The physiological ecology of South American mammals In: M.A. Mares and H.H. Genoways, editors, Mammalian biology in South America. Special Publication Series, Pymatuning Laboratory of Ecology, University of Pittsburg, Linesville, PA.

1982b. Evolutionary alternatives in the physiological ecology of bats. In: T.H. Kunz, editor, Ecology of bats. Plenum Press, New York, NY.

Magle, S.B., D.M. Theobald, and K.R. Crooks. 2009. A comparison of metrics predicting landscape connectivity for a highly interactive species along an urban gradient in Colorado, USA. Landscape Ecology 24: 267-280.

Merriam, C.H. 1890. Results of a biological survey of the San Francisco Mountain region and desert of the Little Colorado, Arizona. North American Fauna No. 3. Washington, DC.

1895. The geographic distribution of animals and plants in North America. Washington, DC.

Miller, G.S., JR. 1897. North American Fauna No. 13: revision of the North American bats of the family
Vespertilionidæ. USDA Division of Biological Survey, Washington, DC.

Navo, K.W., and P. Krabacher. 2005. The use of bat gates at abandoned mines in Colorado. Bat Research News 46:1-8.

O'Farrell, M.J., and E.H. Studier. 1980. Myotis thysanodes. Mammalian Species 137:1-5.

O'Shea, T.J., M.A. Bogan, and L.E. Ellison. 2003. Monitoring trends in bat populations of the United States and territories: status of the science and recommendations for the future. Wildlife Society Bulletin 31:16-29.

O’Shea, T.J., P.M. Cryan, E.A. Snider, E.W. Valdez, L.E. Ellison, and D.J. Neubaum. 2011. Bats of Mesa Verde National Park, Colorado: composition, reproduction, and roosting habits. Monographs of the Western North American Naturalist 5:1-19.

Patterson, B.D., V. Pacheco, and S. Solari. 1996. Distributions of bats along an elevational gradient in the Andes of southeastern Peru. Journal of Zoology (London) 240:637-658.

Ray, A.J., J.J. Barsugli, K.B. Averyt, K. Wolter, M. Hoerling, N. Doesken, B. Udall, and R.S. Webb. 2008. Climate change in Colorado: a synthesis to support water resources management and adaptation. A report by the Western Water Assessment for the Colorado Water Conservation Board, Denver, Colorado. $52 \mathrm{pp}$.

Rodhouse, T.J., P.C. Ormsbee, K.M. Irvine, L.A. VierLing, J.M. SzewCZAK, AND K.T. VierLing. 2012. Assessing the status and trend of bat populations across broad geographic regions with dynamic distribution models. Ecological Applications 22:1098-1113.

Saunders, S., C. Montgomery, T. Easley, and T. Spencer. 2008. Hotter and drier: the West's changed climate. The Rocky Mountain Climate Organization and the Natural Resources Defense Council. 54 pp.

Sikes, R.S., W.L. Gannon, and the Animal Care and Use Committee of the American Society of Mammalogists. 2011. Guidelines of the American Society of Mammalogists for the use of wild animals in research. Journal of Mammalogy 92:235-253.

Soriano, P.J., A. Díaz de Pascual, J. Ochoa G., and M. Aguilera. 1999. Biogeographic analysis of the mammal communities in the Venezuelan Andes. Interciencia 24:17-25.

Studier, E.H., AND M.J. O’FarRell. 1972. Biology of Myotis thysanodes and M. lucifugus (Chiroptera: Vespertilionidae).-I. Thermoregulation. Comparative Biochemistry and Physiology 41A:567-595.

[USFWS] United States Fish and Wildlife Service. 1994. 50 CFR Part 17. Endangered and threatened wildlife and plants; notice of final decision on identification of candidates for listing as endangered or threatened. Federal Register 61(235):64481-64485.

1996. 50 CFR Part 17. Endangered and threatened wildlife and plants: notice of final decision on identification of candidates for listing as endangered or threatened. Federal Register 61(235):64481-64485.

2012. North American bat death toll exceeds 5.5 million from white-nose syndrome. USFWS; [accessed 26 April 2012]; http://www.fws.gov/whitenosesyn drome/pdf/wns_mortality_2012_nr_final.pdf

[USFS] United Stätes Forest Service. 2006. Forest Service Manual Rocky Mountain Region (Region 2), Denver, Colorado, FSM 2600-Wildlife, fish, and sensitive plant habitat management, Chapter 2670- 
Threatened, endangered and sensitive plants and animals. Supplement No. 2600-2006-1 [3 May 2006], Denver, CO.

WELLER, T.J. 2008. Using occupancy estimation to assess the effectiveness of a regional multiple-species conservation plan: bats in the Pacific Northwest. Biological Conservation 141:2279-2289.

WiLley, M.J. 2010. Effects of elevation and associated temperature and insect biomass on abundance, diversity, and distribution of male and female bats in the Front Range of Colorado. Master's thesis, University of Colorado, Greeley, CO.
Willig, M.R., S.K. Lyons, And R.D. Stevens. 2009. Spatial methods for the macroecological study of bats. In: T.H. Kunz and S. Parsons, editors, Ecological and behavioral methods for the study of bats. 2nd edition. Johns Hopkins University Press, Baltimore, MD.

Wilson, D.E., AND D.M. ReEDER, EDITORs. 2005. Mammal species of the world: a taxonomic and geographic reference. 3rd edition. John Hopkins University Press, Baltimore, MD.

Received 10 January 2014 Accepted 17 October 2014 